Proc. Estonian Acad. Sci. Eng., 2005, 11, 3, 226-233

\title{
Group-mode performance of wind turbine generators
}

\begin{abstract}
Teolan Tomson
Department of Materials Science, Tallinn University of Technology, Ehitajate tee 5, 19086 Tallinn, Estonia; teolan@anet.ee

Received 6 June 2003, in revised form 7 June 2004

Abstract. In the paper the influence of the wind power increments on the group-mode performance of wind turbine generators (WTG) has been studied. It is proved that with increasing distance between WTGs, the suppression of global wind power increments in the group will increase. Wind power increments in the sheltered landscape (inland) are lower than in the coastal zone and the positive effect of group-mode performance is reduced.
\end{abstract}

Key words: wind power, wind turbine generator, group-mode performance.

\section{INTRODUCTION}

Estonia has notable length of the coastal line and it is possible to disperse the generation of wind energy. Dispersion of wind turbine generators would have no effect in the meaning of the running reserve if the wind power is considered to be a stationary stochastic process $\left[{ }^{1}\right]$. The situation is different when we have to reduce high wind power increments, caused by wind fronts, which disturb the performance of the energy system with inertial power plants $\left[{ }^{2}\right]$. The wind power increment is the difference of generated power at one-hour time interval $\left[^{3}\right]$. We shall consider only the absolute values of the increments. In $\left[{ }^{4}\right]$ different behaviour of wind speed and wind power increments at different heights (10 and $50 \mathrm{~m}$ ) has been investigated. Recently the wind speed has been measured at the technological height of $30-40 \mathrm{~m}$ and it is possible to make needed corrections. The main goal of this paper is to investigate how the distance between WTGs influences their group-mode performance. 


\section{DATA SERIES}

We can use simultaneous data from four different sites in the north-western Estonia from November 2002 to February 2003. The distances between the sites are from 30 to $90 \mathrm{~km}$. We can also use the data from three Swedish wind monitors located at Näsudden (NSD, the Island of Gotland) with distances between them from 1.4 to $6 \mathrm{~km}$. These data were recorded from May 2000 until June 2002 (with some interruptions, which were levelled by data processing). All these measurements were recorded with a 10-minute sampling interval, but we used every third measurement. It means, we investigated one-hour increments $\Delta P^{*}$ of the relative wind capacity $P^{*}$ with a half-hour step:

$$
\Delta P^{*}=\left|P^{*}(i)-P^{*}(i+2)\right|,
$$

where $i$ is the number of the sampling.

More frequent sampling would bring about overlapping increments when the wind speed increases modestly. Characteristics of the monitoring sites in the north-western Estonia and Gotland Island are presented in Table 1 and Estonian monitors are shown in Fig. 1.

The Land Tower (LT) $\left.{ }^{5}\right]$ is located at $1.4 \mathrm{~km}$ from the coast in the sheltered landscape with different obstacles. The Coastal Tower (CT) is located on the waterline and Sea Tower (ST) in the middle of the Bockstigen wind park, $4.4 \mathrm{~km}$ from the coast. The measured "instant"1 wind speeds are converted into "instant" relative capacities according to $\left[{ }^{1}\right]$. The relative unit capacity $P^{*}$ equals to 1 , if the WTG performs at its rated power. We can easily transform the unit capacity to the real one with a multiplier, if required. For the group-mode performance, we have assumed that the whole group consists of units with unit capacities and this group has a common time basis. The groups have independent time bases. Due to the different wind conditions, the average values of wind speed, wind power and wind power increments are different in the groups.

Table 1. Wind monitoring sites

\begin{tabular}{|c|c|c|c|c|c|c|}
\hline \multirow{2}{*}{ Site } & \multirow{2}{*}{ Abbreviation } & \multicolumn{2}{|c|}{ Coordinates } & \multirow{2}{*}{$\begin{array}{l}\text { Height, } \\
\text { m }\end{array}$} & \multirow{2}{*}{$\begin{array}{c}\text { Average } \\
\text { wind speed, } \\
\mathrm{m} \mathrm{s}^{-1}\end{array}$} & \multirow{2}{*}{$\begin{array}{l}\text { Interval } \\
\text { analysed }\end{array}$} \\
\hline & & $\mathrm{N}$ & $\mathrm{E}$ & & & \\
\hline Avaste & AVA & $58^{\circ} 37^{\prime}$ & $24^{\circ} 05^{\prime}$ & 27 & 4.3 & \\
\hline Rohuküla & RHK & $58^{\circ} 55^{\prime}$ & $23^{\circ} 28^{\prime}$ & 40.5 & 5.5 & $12.2002-$ \\
\hline Ristna & RSN & $59^{\circ} 17^{\prime}$ & $23^{\circ} 44^{\prime}$ & 32 & 7.1 & 02.2003 \\
\hline Türisalu & TRS & $59^{\circ} 25^{\prime}$ & $24^{\circ} 19^{\prime}$ & 40.5 & 5.8 & \\
\hline Land Tover & LT & $\sim 57^{\circ} 10^{\prime}$ & & 58 & 8.0 & \\
\hline Coastal Tover & CT & & $\sim 18^{\circ} 12^{\prime}$ & 60 & 7.9 & $05.2000-$ \\
\hline Sea Tover & ST & & & 45 & 6.0 & \\
\hline
\end{tabular}

1 In fact the average over a 10-minute interval. 


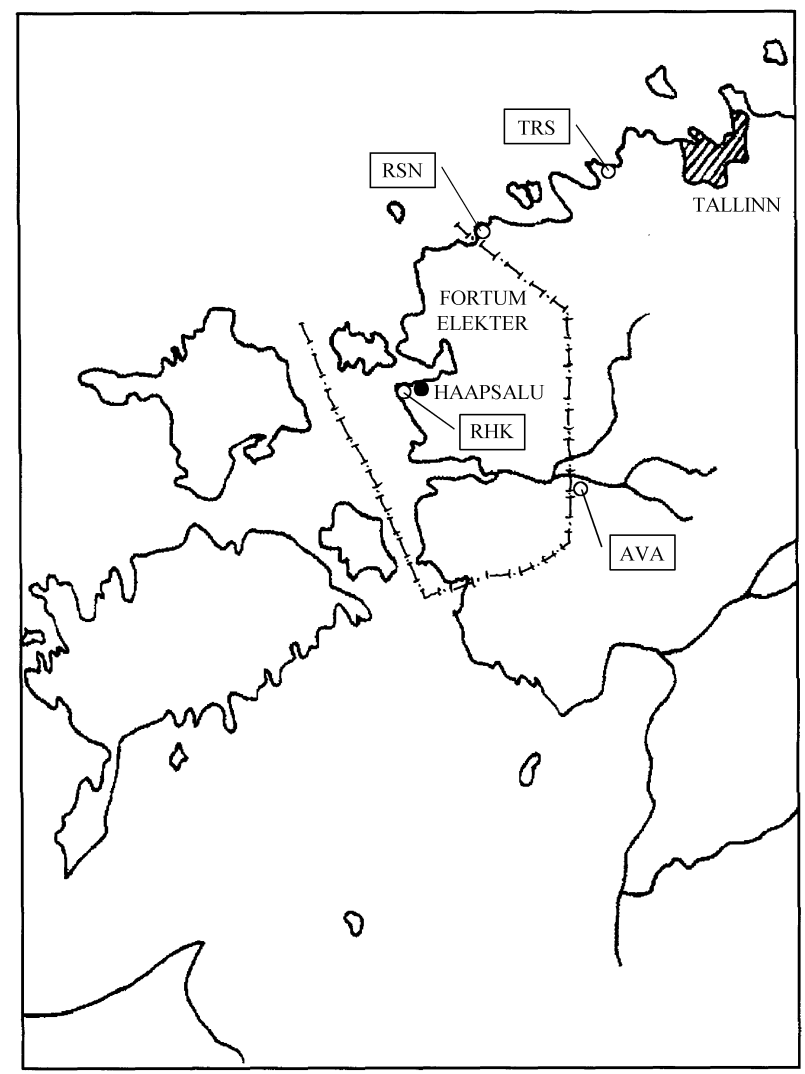

Fig. 1. Wind monitoring sites in north-western Estonia.

\section{THE FREQUENCY OF WIND POWER INCREMENTS}

The wind power increments are caused by transient processes and the assumption about the steady-state stochastic behaviour of wind $\left[{ }^{6-8}\right]$ can not be used in this case. The wind power increments can be ordered by their value and for each range of values its frequency (probability) $\Phi$ can be established. The frequency of big increments $\left(\Delta P^{*}>0.5\right)$ is low and they can be found only in a very long data series. In Table 2 the available databases for the assessment of wind power increments are characterized.

The result of the analysis is presented in Fig. 2. We can see that the frequency distribution of the increments is very close to an exponential function. From Fig. 2 we can conclude:

1) in spite of a very long database no $100 \%$ increment $\left(\Delta P^{*}=1\right)$ is present and the frequency of big increments is really low ${ }^{2}$;

2 These increments are possible, but they are hidden as we have a discrete sequence of the measured values. 
Table 2. Databases for the assessment of large-scale wind power increments

\begin{tabular}{l|c|c|c|c|c}
\hline \multicolumn{1}{c|}{ Site } & $\begin{array}{c}\text { Height, } \\
\mathrm{m}\end{array}$ & Period of measurements & $\begin{array}{c}\text { Number of } \\
\text { samplings }\end{array}$ & $\begin{array}{c}\text { Average } \\
\text { speed, } \\
\mathrm{m} \mathrm{s}^{-1}\end{array}$ & $\begin{array}{c}\text { Average } \\
\text { relative } \\
\text { capacity }\end{array}$ \\
\hline NSD, LT & 38 & $01.01 .85-31.12 .87$ & 25840 & 6.72 & 0.216 \\
RSN & 32 & $26.09 .01-15.05 .03$ & 19365 & 7.30 & 0.248
\end{tabular}

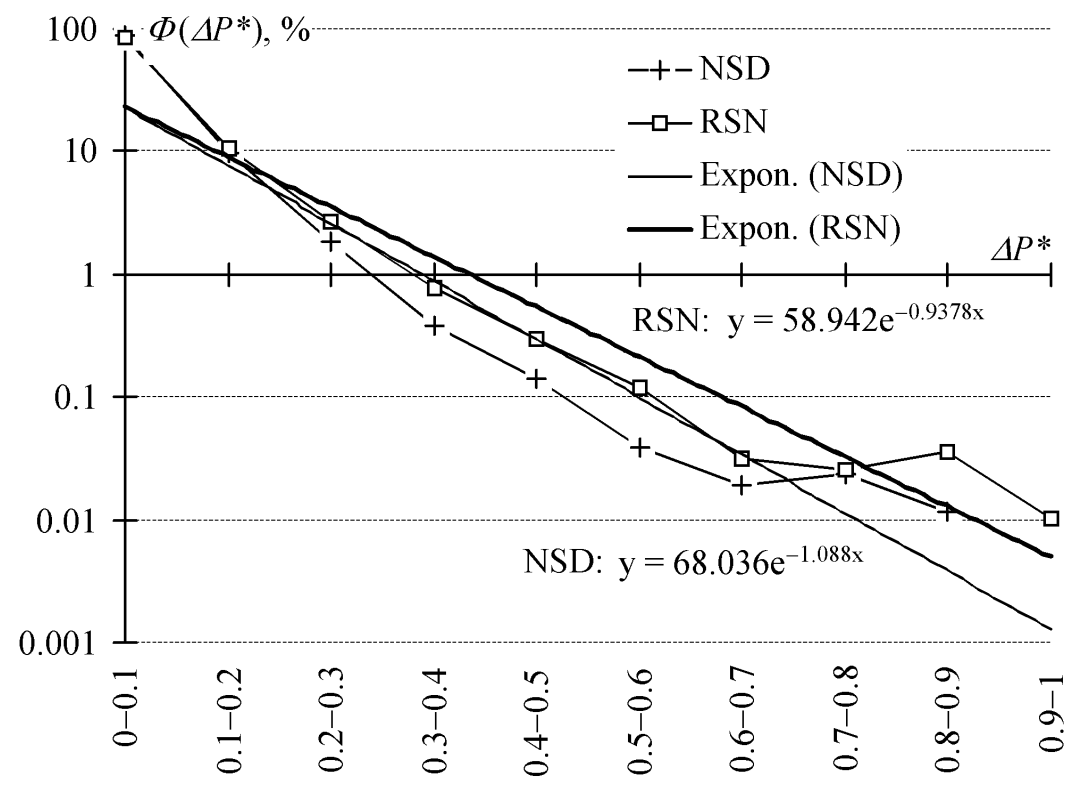

Fig. 2. Wind power increments during a long period.

2) the Ristna site RSN is located just on the coastline; due to that, it has a higher average value of the wind speed and wind power; the probability of big wind power increments is higher there.

Thus we may conclude that the sheltered landscape reduces not only the average wind speed but also the wind power increments.

\section{THE GROUP-MODE PERFORMANCE}

The present study is devoted to the solution of the following problems.

1. Will the low frequency of big wind power increments, proved for the wind measured at the $10 \mathrm{~m}$ level, be valid also for technological heights $(40-50 \mathrm{~m})$ ?

2. Will this effect depend on the distance between the wind generators?

To solve these problems, the wind power increments for pairs of wind generators are compared with the increments of each WTG in the pairs and with 
the global wind power increment of the whole group. In the first group (northwestern Estonia, AVA-RHK, AVA-RSN, AVA-TRS, RHK-RSN, RHK-TRS and RSN-TRS), the distances are from 30 to $90 \mathrm{~km}$. In the second group (the Näsudden area, ST-CT, ST-LT and CT-LT), the distances are from 1.5 to $6 \mathrm{~km}$. The probability of an increment with a certain value in the pair is always lower than for each site in the pair.

\section{EFFECT OF THE INCREMENT SUPPRESSION IN THE GROUP}

The probability of an increment with a certain value in a group is always lower than for each pair in the group. Averaged characteristics are shown in Figs. 3 to 6. In Fig. 3, the average frequency distribution diagram for different sites in northwestern Estonia is shown with the curve "Av. site", the average frequency distribution diagram for pairs is shown with the curve "Av. pair" and for the group of four sites with the curve "Sum of NWE". The quality of suppression can be measured with the value of the power of the exponential trend line. The higher absolute value of this power indicator corresponds to better suppression effect. In Fig. 4 the probability distribution of the wind power increments in Näsudden is shown as an average of three sites (Av. NSD) and for their group (Sum NSD). Figures 3 and 4 show that due to the higher wind speed (Table 1), the wind power increments in Näsudden are bigger and their probability does not decrease so fast. The reducing effect of the group performance is less than that in north-western Estonia.

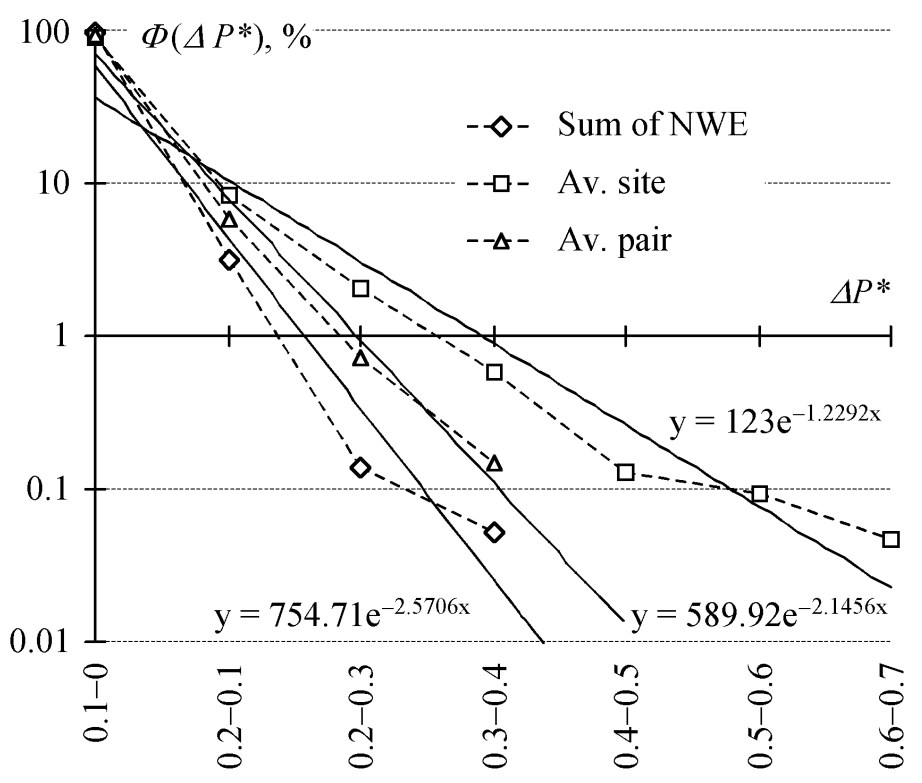

Fig. 3. Effect of the group-mode performance of WTGs: the case of north-western Estonia. 


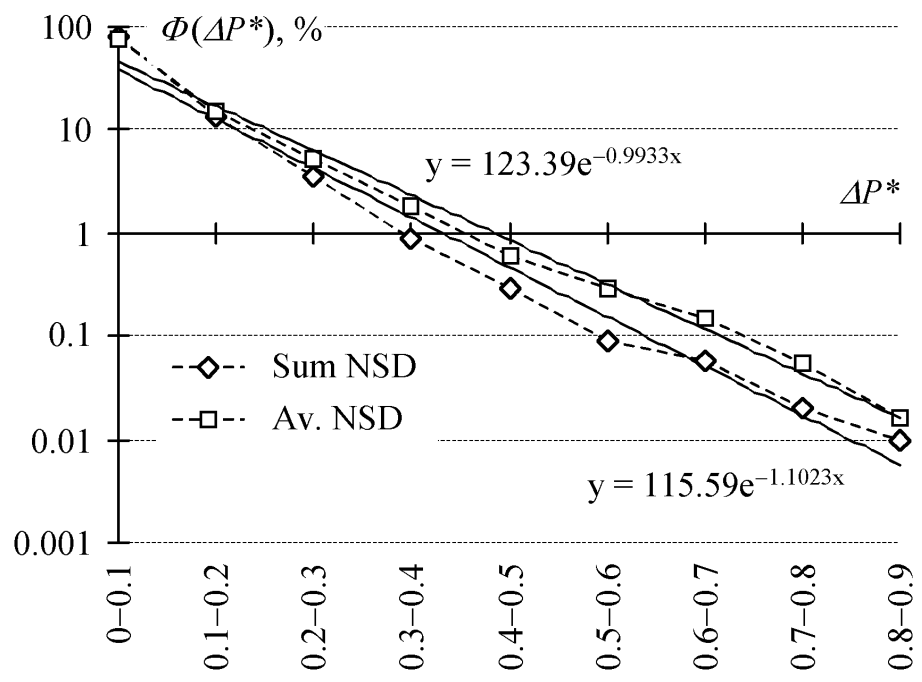

Fig. 4. Effect of the group-mode performance of WTGs: the case of Näsudden, Gotland.

This feature is especially well seen in Fig. 5 where the average values and increments of the group-mode performance are presented for both sites. This phenomenon has two origins. First, the number of WTGs in Gotland is less and, second, the distances inside the group are smaller. Below we will see how the distance influences the damping effect of power increments.

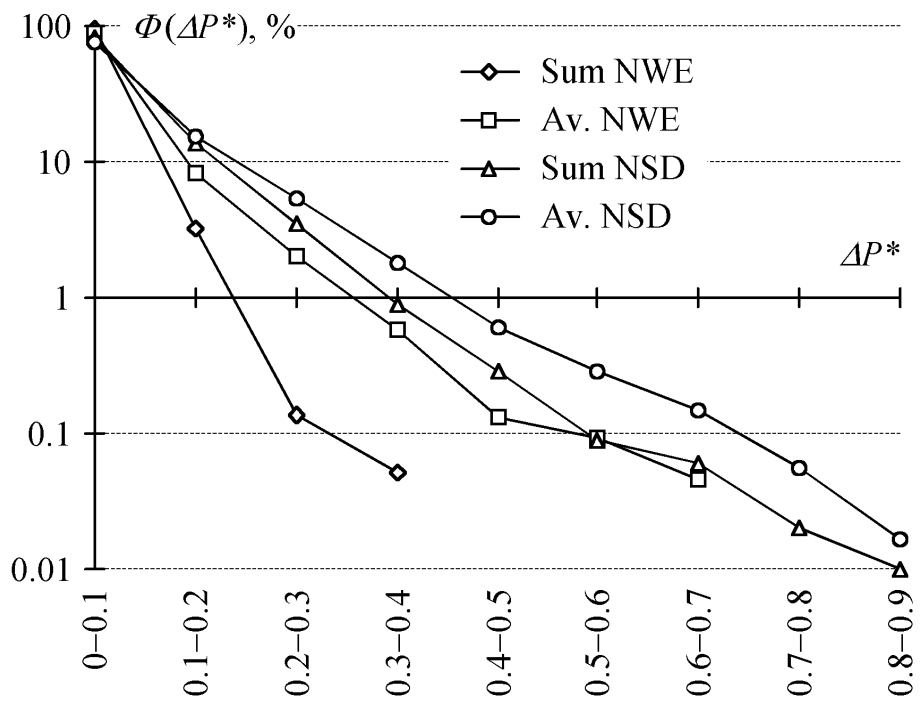

Fig. 5. Comparison of the group-mode performances in north-western Estonia and Näsudden. 


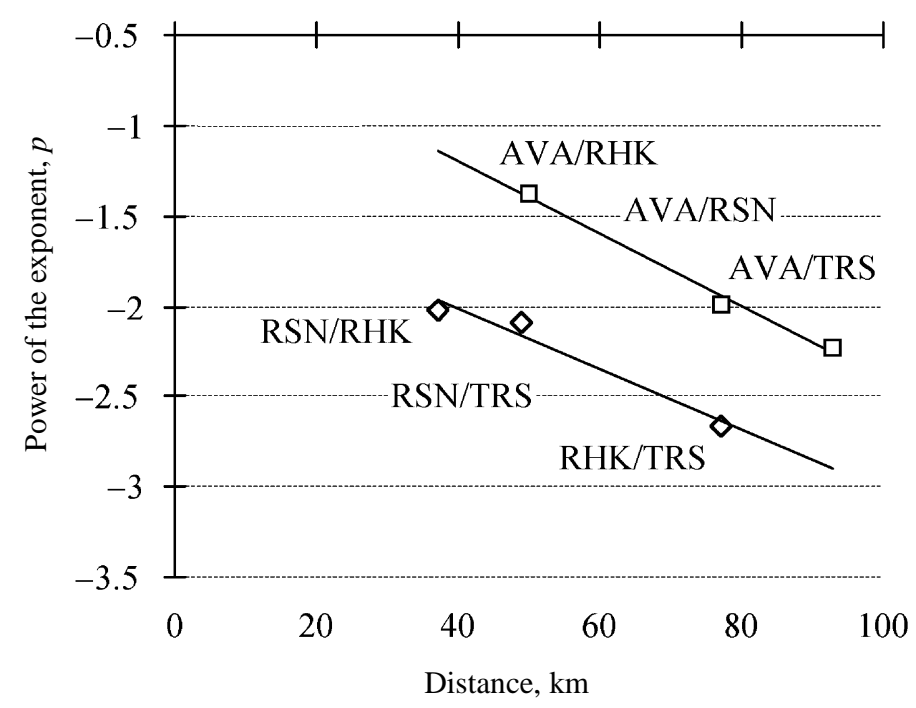

Fig. 6. Dependence of the suppression of the wind power increments on their distance.

\section{DEPENDENCE OF THE EFFECT OF SUPPRESSION OF THE WIND POWER INCREMENTS ON THE DISTANCE BETWEEN WTG-S}

Dependence of the suppression effect of wind power increments on the distance between the WTGs is presented in Fig. 6 for north-western Estonia through the dependence of the power $p$ of the exponential function on the distance. Higher absolute value of $p$ corresponds to stronger suppression effect. We can see that with an increase of the distance the suppression effect increases. Comparing the pairs AVA/RHK and RHK/TRS, we see that the suppression is less if an inland site is included. Thus we can conclude that the sheltered continental landscape suppresses the wind speed (wind power) and has also an impact on the suppression of the increments.

\section{CONCLUSIONS}

1. There is no principal difference whether the suppression effect of wind power increments is investigated using the data measured at $10 \mathrm{~m}$ or at the technological height $40-50 \mathrm{~m}$.

2. The suppression effect of wind power increments increases with the distance in a group of WTGs (Fig. 6).

3. The sheltered continental landscape suppresses the wind speed (and wind power), but has also an impact on the suppression of increments. 


\section{ACKNOWLEDGEMENT}

The author is thankful to the Estonian Science Foundation for supporting this investigation (grant No. 5051).

\section{REFERENCES}

1. Tomson, T., Leppiman, A. and Tepp, J. Correlation of concentrated and dispersed wind power generation with power consumption. In Proc. European Wind Energy Conference. Madrid, 2003 (CD-ROM).

2. Tomson, T. and Nõva, A. Geographically distributed wind turbines on the West-Estonian coast. Agricult. Eng. Internat., 2001, 3 (http://cigr-ejournal.tamu.edu/articles.html).

3. Durstewitz, M., Ensslin, C., Hoppe-Kilpper, M. and Rohrig, K. Electrical power from widelydispersed wind turbines. In Proc. European Wind Energy Conference. Dublin, 1997, 743746.

4. Tomson, T. and Hansen, M. Behaviour of wind speed fronts. Proc. Estonian Acad. Sci. Eng., 2005, 11, 215-225.

5. Ronsten, G., Thor, S.-E., Ganander, H., Johansson, H., Thiringen, T., Petru, T. and Bergström, H. Evaluation of loads, power quality, grid integration, meteorological conditions and power performance of the first Swedish offshore wind farm at Bockstigen. In Proc. Second International Workshop on Transmission Networks for Offshore Wind Farms. Stockholm, RIT, 2001, 1(17)-17(17).

6. Persaud, S., Fox, B. and Flynn, D. Impact of wind energy development on the operation of an isolated thermal power system. In Proc. European Wind Energy Conference. Copenhagen, 2001, 1207-1210.

7. Persaud, S., Fox, B., Flynn, D. and Milborrow, D. Wind variability effects. In Proc. World Renewable Energy Congress VII. Cologne, 2002 (CD-ROM).

8. Tomson, T. and Hansen, M. Seasonal wind stability on the West Estonian coast. Proc. Estonian Acad. Sci. Eng., 2001, 7, 212-221.

\section{Elektrituulikute grupi funktsioneerimine}

\section{Teolan Tomson}

On uuritud elektrituulikute võimsuse muute seoses tuule kiiruse muutumisega. On näidatud, et grupiviisilisel tööl sõltub summaarse muudu mahasurumine elektrituulikute vahemaast ja paraneb selle suurenemisega. Sisemaa suletud maastik vähendab tuulekiiruse keskväärtust, tuulevõimsuse muute ja ka muutude mahasurumise efekti tuulikute grupi funktsioneerimisel. Järeldused, mis varem olid tehtud madalal $(10 \mathrm{~m})$ mõõdetud tuule omaduste põhjal, kehtivad ka tehnilisel kõrgusel (40-50 m) mõõdetud tuuleandmete puhul. 